\title{
Soybean hulls and / or white oat grains on the ingestive behavior of confined steers
}

\section{Casca do grão de soja e / ou grão aveia branca no comportamento ingestivo de novilhos confinados}

\author{
Guilherme Joner ${ }^{*}$; Dari Celestino Alves Filho²; Andrei Retamoso Mayer³; Patrícia \\ Machado Martini Cattelam4; Camille Carijo Domingues; ${ }^{5}$ Mauren Burin da Silva; \\ Joziane Michelon Cocco ${ }^{4}$; Gilmar dos Santos Cardoso 5 ; Ana Paula Machado \\ Martini $^{5}$; Ivan Luiz Brondani
}

\begin{abstract}
Dry matter and neutral detergent fiber contents act as physical regulators of voluntary intake in ruminants. Therefore, different levels of these components may interfere with animal performance and require careful assessment of the used raw material. This study was conducted with the purpose to assess the effect of soybean hulls and white oat in distinct or associated uses in the concentrate diet on the ingestive behavior of cattle. Thirty-six steers with an initial mean age of 20 months and initial mean weight of $226 \mathrm{~kg}$ were used. The diet was composed of $50 \%$ sorghum silage and $50 \%$ concentrate based on dry matter. The tested diets were soybean hulls (concentrate fraction composed mainly of soybean hulls), white oat grains (concentrate fraction composed mainly of white oat grains), and mixture (concentrate fraction composed of equal parts of soybean hulls and white oat grains). The experimental design was a randomized block design with 12 animals per diet. The data were compared by the PROC MIXED procedure with repeated measures in time, and the means were compared by the least significant difference test at 5\% significance level. Diets presented different contents of neutral detergent fiber $(66,56$, and $47 \%)$ and lignin $(3.2,3.7$, and $4.1 \%)$ as the percentage of white oat grain increased in the diet. The total rumination time was lower (447 minutes) for animals that received equal parts of soybean hulls and white oat grains in the diet when compared to animals receiving a diet containing soybean hulls (483 minutes) and white oat grains (495 minutes), with no difference from each other. Animals fed a diet containing soybean hulls and white oat grains showed longer feeding time, a higher number of daily meals, shorter rumination time, shorter time spent chewing, and fewer number of chews per bolus and day. This diet results in a better dry matter and neutral detergent fiber rumination efficiencies.
\end{abstract}

Key words: Avena sativa. Food intake. Chewing. Idling. Rumination.

\footnotetext{
1 Zootecnista, Dr., Universidade Federal do Pampa, UNIPAMPA, Campus Dom Pedrito, Dom Pedrito, RS, Brasil. E-mail: guilhermejoner@unipampa.edu.br

2 Profs. Drs., Departamento de Zootecnia, Universidade Federal de Santa Maria, UFSM, Santa Maria, RS, Brasil. E-mail: darialvesfilho@hotmail.com; brondani@pesquisador.cnpq.br

3 Prof. Dr., Instituto de Desenvolvimento Educacional do Alto Uruguai, IDEAU, Passo Fundo, RS, Brasil. E-mail: andreirm@bol. com.br

4 Discentes, Curso de Mestrado do Programa de Pós-Graduação em Zootecnia, UFSM, Santa Maria, RS, Brasil. E-mail: patriciammartini@hotmail.com; jozimichelon@hotmail.com

5 Discentes, Curso de Doutorado do Programa de Pós-Graduação em Zootecnia, UFSM, Santa Maria, RS, Brasil. E-mail: camidomingues1@gmail.com; maurenburin@hotmail.com; cardosogilmar@bol.com.br; anapaulamartini@zootecnista.com.br

* Author for correspondence
} 


\section{Resumo}

Os teores de matéria seca e fibra em detergente neutro atuam como reguladores físicos do consumo voluntário em ruminantes. Assim, diferentes níveis destes componentes podem interferir no desempenho animal e necessitam de avaliação criteriosa da matéria-prima utilizada. O estudo foi conduzido com o objetivo de avaliar o efeito da casca do grão de soja e a aveia branca, em usos distintos ou associados na dieta concentrada no comportamento ingestivo de bovinos. Utilizou-se 36 novilhos com idade média inicial de 20 meses e peso médio inicial de $226 \mathrm{~kg}$. A dieta foi composta de $50 \%$ de silagem de sorgo e $50 \%$ de concentrado com base na matéria seca. As dietas testadas foram: casca do grão de soja (fração concentrada composta principalmente por casca do grão de soja), grão de aveia branca (fração concentrada composta principalmente por grão de aveia branca) e mistura (fração concentrada composta por partes iguais de casca do grão de soja e grão de aveia branca). O delineamento experimental foi blocos ao acaso com 12 animais por dieta. Os dados foram comparados pelo procedimento PROC MIXED com avaliações repetidas no tempo e as médias, comparadas pelo teste de diferença mínima significativa ao nível de $5 \%$ de significância. As dietas apresentaram diferentes teores de fibra em detergente neutro $(66,56$ e $47 \%$ ) e lignina $(3,2 ; 3,7$ e 4,1 \%) conforme aumento da participação do grão de aveia branca na dieta. O tempo de ruminação total foi inferior (447 minutos) para animais que receberam partes iguais de casca do grão de soja e grão de aveia branca na dieta em relação a animais recebendo dieta contendo casca do grão de soja (483 minutos) e grão de aveia branca (495 minutos), que não deferiram entre si. Animais alimentados com a dieta contendo casca de grão de soja e grão de aveia branca apresentaram maior tempo de alimentação, maior número de refeições diárias, menor tempo de ruminação, menor tempo despendido para mastigação, menor número de mastigadas por bolo e no dia. Tal dieta resulta em melhor eficiência de ruminação de matéria seca e de fibra em detergente neutro.

Palavras-chave: Avena sativa. Consumo de alimento. Mastigações. Ócio. Ruminação.

\section{Introduction}

The study of the ingestive behavior of cattle is important to obtain better nutritional parameters for the preparation of diets for ruminants. According to Lima et al. (2003), it is possible to assess the effects of feeding or the quantity and nutritional quality of food, the relationship between ingestive behavior and voluntary intake, and the potential use of knowledge on the ingestive behavior to improve animal performance (CATTELAM et al., 2013). Moreover, Mendonça et al. (2004) observed that the data of ingestive behavior could be used in the assessment of diets. It allows adjusting food management for better productive performance.

The type of food or diet is considered in the assessment of ingestive behavior (PINTO et al., 2010), and the main component of food intake regulation is the fiber content (VAN SOEST, 1994). The highest proportion of fiber decreases the intake of other nutrients, but fiber still guarantees ruminal function and microbial growth in the rumen
(PEREIRA et al., 2007).

Because it is not a nutritionally uniform fraction (VAN SOEST, 1994), the use of this fraction in diet formulation demands complex knowledge. According to Pereira et al. (2007), other factors related to fiber, such as digestibility, particle size, density, and rate of passage affect food intake.

Among the potential foods for use in animal nutrition are the soybean hulls and white oat, which behave as concentrate-roughage foods. Soybean hulls have a high crude fiber content $(42.76 \%)$, in which neutral detergent-soluble fibers represent $69.20 \%$ and acid detergent-soluble fibers $43.02 \%$, with the fiber found in soybean hulls being highly digestible (ZAMBOM et al., 2001). White oat is the cereal with the highest crude fiber content, averaging $10 \%$, while the other cereals reach no more than 3\%. However, the lignin present in oat grain hulls (5.5 to $6.0 \%)$ has a negative influence on digestibility when it is offered without mechanical processing (THOMPSON et al., 2000). 
In addition to the factors resulting from the diet offered to animals, Pinto et al. (2010) emphasize that there are factors related to the animal that determine the ingestive behavior of ruminants such as digestive tract capacity, ability to digest nutrients, and acidity and osmolarity of the rumen.

This study was carried out with the purpose to assess the ingestive behavior of steers receiving diets containing soybean hulls and/or white oat to elucidate the potential use of these ingredients in feedlot diets.

\section{Material and Methods}

The experiment was carried out at the Laboratory of Beef Cattle of the Department of Animal Science of the Federal University of Santa Maria, located in the Central Depression of the Rio Grande do Sul State, at an average altitude of $95 \mathrm{~m}$ and geographical coordinates of $29^{\circ} 43^{\prime} \mathrm{S}$ and $53^{\circ} 42^{\prime} \mathrm{W}$. Thirty-six purebred Charolais and Nellore steers, as well as animals from the crossing of these two breeds, with an initial mean age and weight of 20 months and $226 \mathrm{~kg}$ of live weight, respectively, from the experimental herd of the Laboratory of Beef Cattle were used.

Animals were finished in a semi-covered feedlot (50\%), with boxes of $20 \mathrm{~m}^{2}$ of area, paved, provided with feeding troughs for supplying food and drinking troughs with water ad libitum, regulated with a float valve. Diets were distributed randomly, with two steers at each box. Animals were adapted to the facilities and diets for 28 days before the experimental period. At this period, endo- and ectoparasites were controlled with the subcutaneous application of ivermectin-based product ( $1 \%$ concentration) at the dose recommended by the manufacturer. The steers were divided into three diets, with roughage to concentrate ratio of 50:50. Roughage consisted of sorghum silage (Sorghum bicolor L Moench) for all diets, and the concentrate fraction contained soybean hulls and/or white oat, soybean meal, urea, calcitic limestone, and common salt (Table 1).

Table 1. Bromatological composition of the ingredients used to prepare the diets.

\begin{tabular}{|c|c|c|c|c|c|c|}
\hline \multirow{2}{*}{ Contents, $\mathrm{g} \mathrm{kg}^{-1}$ of DM } & \multirow{2}{*}{ Sorghum silage } & \multicolumn{2}{|c|}{ Soybean } & \multirow{2}{*}{ White oat grain } & \multirow{2}{*}{ Calcitic limestone } & \multirow{2}{*}{ Urea } \\
\hline & & Meal & Hulls & & & \\
\hline $\mathrm{DM}^{\#}$ & 315.64 & 908.16 & 887.13 & 917.59 & 1000.0 & - \\
\hline $\mathrm{OM}$ & 949.76 & 934.12 & 956.93 & 973.03 & 736.7 & - \\
\hline MM & 50.24 & 65.88 & 43.07 & 26.97 & 363.3 & - \\
\hline $\mathrm{CP}$ & 46.11 & 511.36 & 119.16 & 119.99 & - & 2812.5 \\
\hline $\mathrm{EE}$ & 18.17 & 22.23 & 6.34 & 54.49 & - & - \\
\hline $\mathrm{ADF}$ & 428.55 & 117.20 & 527.51 & 131.71 & - & - \\
\hline NDF & 685.67 & 142.24 & 722.66 & 288.81 & - & - \\
\hline NDIN & 2.42 & 3.98 & 7.78 & 0.97 & - & - \\
\hline ADIN & 1.56 & 2.20 & 1.03 & 0.45 & - & - \\
\hline LIG & 56.66 & 2.08 & 9.18 & 29.66 & - & - \\
\hline TDN & 566.66 & 821.47 & 662.83 & 802.08 & - & - \\
\hline IVDOM* & - & - & 915.00 & 764.00 & - & - \\
\hline $3 \mathrm{~h}$ & - & - & 7.20 & 14.80 & - & - \\
\hline $6 \mathrm{~h}$ & - & - & 14.50 & 37.60 & - & - \\
\hline $12 \mathrm{~h}$ & - & - & 28.00 & 57.40 & - & $\begin{array}{c}- \\
\text { contin }\end{array}$ \\
\hline
\end{tabular}


continuation

\begin{tabular}{ccccccc}
$24 \mathrm{~h}$ & - & - & 53.50 & 67.90 & - & - \\
$48 \mathrm{~h}$ & - & - & 82.50 & 73.30 & - & - \\
$72 \mathrm{~h}$ & - & - & 91.50 & 76.40 & - & - \\
\hline
\end{tabular}

${ }^{\#} \mathrm{~g} \mathrm{~kg}^{-1}$ of Natural matter

* \% of Organic matter

- values not determined

$\mathrm{DM}=$ dry matter; $\mathrm{OM}=$ organic matter; $\mathrm{MM}=$ mineral matter; $\mathrm{CP}=$ crude protein; $\mathrm{EE}=$ ethereal extract; $\mathrm{ADF}=$ acid detergent fiber; NDF = neutral detergent fiber; NDIN = neutral detergent insoluble nitrogen; ADIN = acid detergent insoluble nitrogen; LIG

= lignin; TDN = total digestible nutrients; IVDOM = in vitro digestibility of $\mathrm{OM}$.

Diets were formulated according to NRC (2001) aiming at a daily live weight gain of $1.20 \mathrm{~kg} \mathrm{aminal}^{-1}$, dry matter intake of $2.55 \%$ of the body weight, and isoproteic diet. The tested diets consisted of soybean hulls (energy-based concentrate of soybean hulls), white oat grain (energy-based concentrate of white oat grain), and mixture (energy-based concentrate in equal parts of soybean hulls and white oat grains).

During the experimental period, animals were fed twice a day (in the morning at $8 \mathrm{~h}$ and in the afternoon at $14 \mathrm{~h}$ ), and the leftovers from the previous day were collected daily before the first feeding and registered in a spreadsheet for intake adjustment purposes. Roughage was supplied in the feeding trough with the concentrate on it, followed by homogenization. Voluntary diet intake was recorded daily by weighing the amount of food offered and leftovers from the previous day. Food supply was pre-established between 5 and 10\% higher than the voluntary intake (FATURI et al., 2006), regulated according to animal intake in the previous day.

Diet ingredients and leftover samples were taken three times a week, being thoroughly homogenized for better sampling. These samples were pre-dried in a forced-air oven at $55^{\circ} \mathrm{C}$ for 72 hours, ground in a Willey mill with a $1 \mathrm{~mm}$ mesh sieve, and packed in air- and moisture-free plastic packages for chemical analysis (AOAC, 1995). Dry matter content was determined by oven drying at $105{ }^{\circ} \mathrm{C}$ until constant weight (Table 2) and ashes by calcination in muffle at $550{ }^{\circ} \mathrm{C}$ until constant weight (AOAC,
1995). Organic matter content was calculated by subtracting the value found for dry matter by the ash value (AOAC, 1995). The total nitrogen content was determined by the Kjeldahl method (AOAC, 1995), modified due to the use of $4 \% \mathrm{w} / \mathrm{v}$ boric acid solution as free ammonium receptor during distillation, 0.2 $\mathrm{w} / \mathrm{v}$ bromocresol green solution, $0.1 \% \mathrm{w} / \mathrm{v}$ methyl red solution as indicator, and standard sulfuric acid solution for titration. The ethereal extract content was determined after treating the samples with ether under reflux at $180{ }^{\circ} \mathrm{C}$ for 2 hours (AOAC, 1995). The contents of neutral detergent fiber, acid detergent fiber, and acid detergent lignin were determined according to Van Soest et al. (1991), and the contents of soluble nitrogen, neutral detergent insoluble nitrogen, and acid detergent insoluble nitrogen according to Licitra et al. (1996). The total digestible nutrient content (TDN) was obtained according to Weiss et al. (1992) by the formula TDN $(\%)=(0.98 \times$ non-fibrous carbohydrates $)+$ $(0.93 \times$ crude protein $)+2.25 \times($ ethereal extract 1) $+0.75 \times$ (neutral detergent fiber crude protein free - lignin $) \times[1-($ lignin/neutral detergent fiber crude protein free) 0.667$]-7$. Digestible energy was calculated according to NRC (2001), in which $1 \mathrm{~kg}$ of the total digestible nutrients $=4.4 \mathrm{Mcal}$ of digestible energy. In vitro digestibility of organic matter of soybean hulls and white oat grains was carried out at a laboratory of the Instituto Nacional de Tecnología Agropecuaria, Estación Experimental Agropecuaria Concepción del Uruguay, Entre Ríos, Argentina, using the technique described by Tilley and Terry (1963). 
The assessments of the ingestive behavior of animals were performed every 21 days for 48 hours without interruption, starting and ending at 8:00 h. Table 3 shows the meteorological data (pressure, temperature, humidity, and precipitation). Feeding, idling, and rumination activities were recorded every 5 min. Rumination time was considered to be the period when the animal was not ingesting food, but chewing the regurgitated food bolus from the rumen. Idling time represents the period when the animal was not feeding or ruminating and included social activities and water intake. In the nocturnal observations of animals, the environment was maintained with artificial lighting. The mean number of rumination chews per ruminal bolus and the mean of time spent with rumination chews per ruminal bolus were obtained through 12 observations per replication on each assessment day. The results referring to the factors of ingestive behavior were obtained by the adapted relationships of Bürger et al. (2000), as follows: DMRE = DMI/TRT, NDFRE $=\mathrm{NDFI} / \mathrm{TRT}$, DCT $=\mathrm{TRT}, \mathrm{NB} \mathrm{D}^{-1}=\mathrm{TRT} / \mathrm{CT} \mathrm{B}^{-1}$,
$\mathrm{NC} \mathrm{D}^{-1}=\mathrm{NC} \mathrm{B}^{-1} \times \mathrm{NB} \mathrm{D}^{-1}, \mathrm{TRT}=\mathrm{SRT}+\mathrm{LRT}$, and $\mathrm{TIT}=\mathrm{SIT}+\mathrm{LIT}$, where DMRE $\left(\mathrm{g} \mathrm{DM} \mathrm{h}^{-1}\right)$ is the dry matter rumination efficiency, DMI $\left(\mathrm{g} \mathrm{DM} \mathrm{day}^{-1}\right)$ is the dry matter intake, TRT (h day ${ }^{-1}$ ) is the total rumination time, NDFRE $\left(\mathrm{g} \mathrm{NDF} \mathrm{h}^{-1}\right)$ is the neutral detergent fiber rumination efficiency, NDFI ( $g$ NDF day $^{-1}$ ) is the neutral detergent fiber intake, DCT (h day $^{-1}$ ) is the daily chewing time, NB D ${ }^{-1}$ (no. day ${ }^{-1}$ ) is the number of bolus chewed per day, $\mathrm{CT} \mathrm{B}^{-1}$ ( $\mathrm{sec}$ bolus $^{-1}$ ) is the chewing time per ruminal bolus, $\mathrm{NC}$ $\mathrm{D}^{-1}$ (no. day $^{-1}$ ) is the number of daily rumination chews during rumination, $\mathrm{NC} \mathrm{B}^{-1}$ (no. bolus ${ }^{-1}$ ) is the number of chews per bolus, SRT $\left(\mathrm{h} \mathrm{day}^{-1}\right)$ is the standing rumination time, LRT $\left(\mathrm{h} \mathrm{day}^{-1}\right)$ is the lying rumination time, TIT $\left(\mathrm{h}\right.$ day $\left.^{-1}\right)$ is the total idling time, SIT (h day ${ }^{-1}$ ) is the standing idling time, and LIT $\left(\mathrm{h} \mathrm{day}^{-1}\right.$ ) is the laying idling time. The number of daily meals was obtained from the permanence of animals in the trough for a minimum of 10 minutes. The mean permanence time in the trough during the meal was obtained by the sum of all the observations divided by the number of meals.

Table 2. Participation of the ingredients in the natural matter and bromatological composition in the dry matter of the diets offered.

\begin{tabular}{|c|c|c|c|}
\hline \multirow{2}{*}{$\begin{array}{l}\text { Ingredients, } \\
\mathrm{g} \mathrm{kg}^{-1} \text { of concentrate }\end{array}$} & \multicolumn{3}{|c|}{ Diets } \\
\hline & Soybean hulls & Mixture & White oat grain \\
\hline White oat grain & - & 421.95 & 811.78 \\
\hline Soybean hulls & 860.06 & 421.95 & - \\
\hline Soybean meal & 128.64 & 137.33 & 162.84 \\
\hline Calcitic limestone & 0.47 & 9.82 & 18.00 \\
\hline Urea & 10.83 & 8.95 & 7.38 \\
\hline \multicolumn{4}{|l|}{ Bromatological composition } \\
\hline Dry matter, $\mathrm{g} \mathrm{kg}^{-1}$ natural matter & 604.30 & 611.26 & 617.78 \\
\hline Crude protein, $\mathrm{g} \mathrm{kg}^{-1}$ dry matter & 124.64 & 122.25 & 124.19 \\
\hline Ethereal extract, $\mathrm{g} \mathrm{kg}^{-1}$ dry matter & 13.27 & 23.60 & 32.99 \\
\hline Mineral matter, $\mathrm{g} \mathrm{kg}^{-1}$ dry matter & 48.12 & 49.73 & 51.15 \\
\hline ADF, $\mathrm{g} \mathrm{kg}^{-1}$ dry matter & 447.82 & 359.64 & 277.17 \\
\hline NDF, $\mathrm{g} \mathrm{kg}^{-1}$ dry matter & 661.15 & 563.88 & 471.45 \\
\hline NDIN, $\mathrm{g} \mathrm{kg}^{-1}$ dry matter & 4.40 & 3.10 & 1.88 \\
\hline Lignin, $\mathrm{g} \mathrm{kg}^{-1}$ dry matter & 32.42 & 36.74 & 40.55 \\
\hline TDN, $\mathrm{g} \mathrm{kg}^{-1}$ dry matter & 626.48 & 650.29 & 677.25 \\
\hline Digestible energy, Mcal kg-1 dry matter & 2.804 & 2.914 & 3.040 \\
\hline
\end{tabular}

$\mathrm{ADF}=$ acid detergent fiber; $\mathrm{NDF}=$ neutral detergent fiber; NDIN $=$ neutral detergent insoluble nitrogen; TDN $=$ total digestible nutrients. 
Table 3. Average daily meteorological measurements for each evaluation day.

\begin{tabular}{ccccc}
\hline Evaluation days & Pressure $(\mathrm{mb})$ & Temperature $\left({ }^{\circ} \mathrm{C}\right)$ & Humidity $(\%)$ & Rainfall $(\mathrm{mm})$ \\
\hline Day 1 & 1008.03 & 11.80 & 83.67 & 0.40 \\
Day 2 & 1009.73 & 12.33 & 82.67 & 0.00 \\
Day 3 & 996.90 & 24.27 & 53.00 & 13.40 \\
Day 4 & 999.53 & 19.40 & 74.33 & 0.00 \\
Day 5 & 1007.23 & 11.33 & 78.33 & 0.00 \\
Day 6 & 1006.53 & 14.60 & 79.00 & 0.00 \\
Day 7 & 1010.83 & 13.60 & 81.67 & 0.00 \\
Day 8 & 997.37 & 16.53 & 82.33 & 0.00 \\
Day 9 & 1005.70 & 21.40 & 76.00 & 0.00 \\
Day 10 & 1006.33 & 20.67 & 83.00 & 0.00 \\
Day 11 & 998.63 & 18.40 & 90.00 & 0.00 \\
Day 12 & 1008.90 & 21.00 & 65.67 & 0.00 \\
\hline
\end{tabular}

Source: Meteorological station of the Federal University of Santa Maria - Department of Plant Science.

The experimental design was a randomized block design with three diets and six replications, with the box being the experimental unit. The animals were blocked by genetic predominance and balanced by fasting live weight (solid and liquid) of 14 hours and assigned to each diet. The data were compared by the PROC MIXED procedure with repeated measures in time. Different covariance structures were tested for each analyzed variable. The data were tested for normality by the Kolmogorov-Smirnov test with $\alpha=0.05$ to assess the ingestive behavior of animals. When non-normal, the following constants were used to reach the normality of the data: $* * 2$ for neutral detergent fiber intake and chewing time per bolus; **4 for dry matter intake; log for the number of daily bolus and number of daily meals; and sqrt for standing rumination time. When any significant difference was detected between the means, they were compared by the least significant difference test with $\alpha=0.05$. A correlation test was also performed between all analyzed variables. The statistical package SAS (STATISTICAL ANALYSIS SYSTEM, 2009) was used for analysis.

For the study, the following mathematical model was used:

$$
\mathrm{Yij}=\mu+\beta \mathrm{i}+\mathrm{Tj}+\left(\beta^{*} \mathrm{~T}\right) \mathrm{ij}+\mathrm{Pk}+\left(\mathrm{T}^{*} \mathrm{P}\right) \mathrm{ik}+\varepsilon \mathrm{ij}
$$

where: Yij are the dependent variables, $\mu$ is the mean of all observations, $\beta i$ is the effect of the $i$-th block corresponding to the genetic predominance of the animal, $\mathrm{Tj}$ is the effect of the $\mathrm{j}$-th treatment, $\left(\beta^{*} \mathrm{~T}\right) \mathrm{ij}$ is the effect of the interaction between the $\mathrm{i}$-th block and the $\mathrm{j}$-th treatment (error a), $\mathrm{Pk}$ is the effect of k-th day, ( $\left.T^{*} \mathrm{P}\right)$ ik is the effect of the interaction between the j-th treatment and the k-th day, and eij is the residual random error (error b).

\section{Results and Discussion}

Feeding time of steers receiving mixture diet (Table 4) was higher when compared to the diets containing soybean hulls and white oat grains. However, diets with soybean hulls and white oat grains presented a 19\% neutral detergent fiber (NDF) difference. According to Moura et al. (2018), a reduction in the roughage portion of the diet and hence NDF content provides a longer time spent feeding at the trough, a result different from that obtained in this study. Van Soest (1994) clarified that the time spent on food consumption and specific weight of the consumed food are variables that influence the efficiency in which the animal harvests food. The increase in intake time 
also tends to reduce the ruminating time per gram of food, a factor that triggers an increase in the fecal particle size when food intake is high (BÜRGER et al., 2000), which could not be observed in our study because there was no significant difference in dry matter intake between diets. According to Pereira et al. (2007), heifers of different genetic groups fed diets with $60 \%$ neutral detergent fiber spent 28.0, 15.8, and 20.2\% longer feeding, rumination, and total chewing activities, respectively, when compared to those fed diets containing 30\% neutral detergent fiber.

Animals fed diet containing soybean hulls and white oat grains had a lower total rumination time when compared to animals fed only soybean hulls or white oat grains. A correlation between rumination time and NDF content $(\mathrm{r}=-0.42 ; \mathrm{P}=$ 0.02) was obtained by Callegaro et al. (2018) when assessing soybean soapstock inclusion levels in the diet $(0-12 \%)$, a result different from that obtained in this study. The authors attributed this correlation by the lack of physically effective fiber provided by the ingredient soybean hulls. The time spent on rumination is directly related to the quality and quantity of diet intake (MENDES et al., 2010). Van Soest (1994) reported that the time spent on rumination is influenced by diet nature and proportion of cell wall content present in the roughage, i.e., the longer the time spent on rumination is, the higher the participation of roughage in the diet.

Table 4. Activities of the feeding behavior of steers fed different types of concentrates in feedlot.

\begin{tabular}{lccccc}
\hline \multirow{2}{*}{ Activity, minutes } & \multicolumn{3}{c}{ Diet } & $\begin{array}{c}\text { Standard } \\
\text { deviation }\end{array}$ & Probability \\
\cline { 2 - 4 } & SH & SH/WO & WO & 31.74 & $<0.0001$ \\
Feeding & $238.99^{\mathrm{b}}$ & $264.00^{\mathrm{a}}$ & $246.18^{\mathrm{b}}$ & 65.54 & 0.0902 \\
Lying idle & 443.05 & 456.32 & 467.12 & 63.90 & $<0.0001$ \\
Standing idle & $274.62^{\mathrm{a}}$ & $270.97^{\mathrm{a}}$ & $231.28^{\mathrm{b}}$ & 64.65 & 0.0256 \\
Total idle & $717.67^{\mathrm{ab}}$ & $727.29^{\mathrm{a}}$ & $698.40^{\mathrm{b}}$ & 64.85 & $<0.0001$ \\
Lying rumination & $431.39^{\mathrm{a}}$ & $374.62^{\mathrm{b}}$ & $439.86^{\mathrm{a}}$ & 54.36 & 0.0025 \\
Standing rumination & $51.94^{\mathrm{b}}$ & $72.50^{\mathrm{a}}$ & $55.03^{\mathrm{b}}$ & 33.60 & $<0.0001$ \\
Total rumination & $483.33^{\mathrm{a}}$ & $447.12^{\mathrm{b}}$ & $495.42^{\mathrm{a}}$ & 49.92 & \\
\hline
\end{tabular}

$\mathrm{SH}=$ soybean hulls; $\mathrm{WO}=$ white oat grain.

a,b,c - means with significant differences by Student's t-test $(\mathrm{P}<0,05)$ have different letters in the same row.

Rumination time was inversely correlated with the number of meals $(66.12 \% ; \mathrm{P}=0.0028)$. Pinto et al. (2010) pointed out that the variables intake and rumination times were not correlated with dry matter and neutral detergent fiber intake. In that study, the animals that spent the shortest food intake time (214.09 $\mathrm{min}$ ) presented the highest dry matter intake $\left(11.73 \mathrm{~kg}\right.$ day $\left.^{-1}\right)$. Furthermore, the authors mentioned several factors that model the real diet intake, such as diet physical and chemical properties, digestibility and degradability of the diet, and individual characteristics of the animal.
Regarding the behavioral activities, Silva et al. (2014) assessed different carbohydrate sources in the diet of confined steers and verified that soybean hulls had shorter feeding times when compared to ground corn and wheat bran, as well as longer idling time and shorter lying rumination time in relation to wheat bran.

When the total rumination time of animals fed mixture diet is sliced, a longer standing rumination time (19 vs. $12 \%$ ) and shorter lying rumination time ( 81 vs. $88 \%$ ) can be observed when compared to 
the other diets. Moura et al. (2018) also obtained shorter standing rumination times when studying confined steers under constant and increasing levels of energy in the diet. Under stress-free environments, ruminants perform rumination lying down. However, with stress, animals spend more time ruminating on their feet (MARQUES et al., 2005).

The total idling and standing times were lower for steers fed white oat grains. The total idling time was inversely proportional to the rumination time, resulting in a correlation of $72.02 \%$. The decrease in idling time and increase in rumination time imply the animal energy loss (PAZDIORA et al., 2011), providing more energy for gain in replacement of the energy required for maintenance with a decrease in physical activity (ARGENTA et al., 2013). According to NRC (2001), this loss may be 10 to $20 \%$ higher in grazing animals.

The number of daily meals (Table 5) was different between diets, differing from each other by the means comparison test. For this characteristic, mixture diet presented the highest number of meals, followed by the diet containing soybean hulls and finally that containing white oat grains. The variation in the content of fibrous components of the diet determines the feeding efficiency of animals (SILVA et al., 2005). In a study that assessed the frequency of diet supply for cattle, Pazdiora et al. (2011) observed that diets with the same content of fibrous components also presented different intake rates.

Table 5. Number and time per daily meal, number and time of daily chewing and bolus of steers fed with different types of concentrates in feedlot.

\begin{tabular}{lccccc}
\hline \multirow{2}{*}{ Variable } & \multicolumn{3}{c}{ Diet } & \multirow{2}{*}{$\begin{array}{c}\text { Standard } \\
\text { deviation }\end{array}$} & Probability \\
\cline { 2 - 4 } & SH & SH/WO & WO & & \\
\hline Number of daily meals, un & $8.89^{\mathrm{b}}$ & $9.72^{\mathrm{a}}$ & $8.03^{\mathrm{c}}$ & 1.77 & $<0.0001$ \\
Average meal time, minutes & $204.86^{\mathrm{b}}$ & $236.87^{\mathrm{a}}$ & $219.58^{\mathrm{b}}$ & 35.62 & $<0.0001$ \\
Number of chews bolus $^{-1}$, un & $62.57^{\mathrm{a}}$ & $59.59^{\mathrm{b}}$ & $62.50^{\mathrm{a}}$ & 6.50 & 0.0025 \\
Chews bolus $^{-1}$, seconds & 57.03 & 54.91 & 60.15 & 5.51 & 0.053 \\
Ruminated boluses day $^{-1}$, un & 515.29 & 498.35 & 502.35 & 70.16 & 0.1867 \\
Chews day $^{-1}$, um & $31895^{\mathrm{a}}$ & $29069^{\mathrm{b}}$ & $30936^{\mathrm{a}}$ & 3609 & 0.0004 \\
Total chewing time, minutes & $520.42^{\mathrm{a}}$ & $477.67^{\mathrm{b}}$ & $511.54^{\mathrm{a}}$ & 69.35 & $<0.0001$ \\
\hline
\end{tabular}

$\mathrm{SH}=$ soybean hulls; $\mathrm{WO}=$ white oat grain.

a,b,c - means with significant differences by Student's t-test $(\mathrm{P}<0,05)$ have different letters in the same row.

The daily food intake is obtained from the number of meals consumed per day, their duration, and animal feeding rate, which is represented by the speed at which each meal is performed (CARVALHO et al., 2008). According to Callegaro et al. (2018), the shorter the time and the distance traveled in the bays, the higher the energy available for muscle development and fat deposition in the carcass.

Meals are usually concentrated near feeding times, which were at 8 and $14 \mathrm{~h}$ in this study (Figure 1). In a study with similar feeding times,
Freitas et al. (2010) and Callegaro et al. (2018) verified a higher presence in times close to feeding and at dusk when assessing the presence of animals in the feeding trough. Animals were conditioned to the management routine. The presence of animals in the trough at $16-18 \mathrm{~h}$ is due to the mild ambient temperature, thus stimulating feeding (CALLEGARO et al., 2018). The mean time per meal was also different between the three diets, with the longest period for the diet containing white oat grains, followed by mixture and soybean hulls. 
Figure 1. Presence to the feeder of steers fed with different types of concentrates in feedlot.

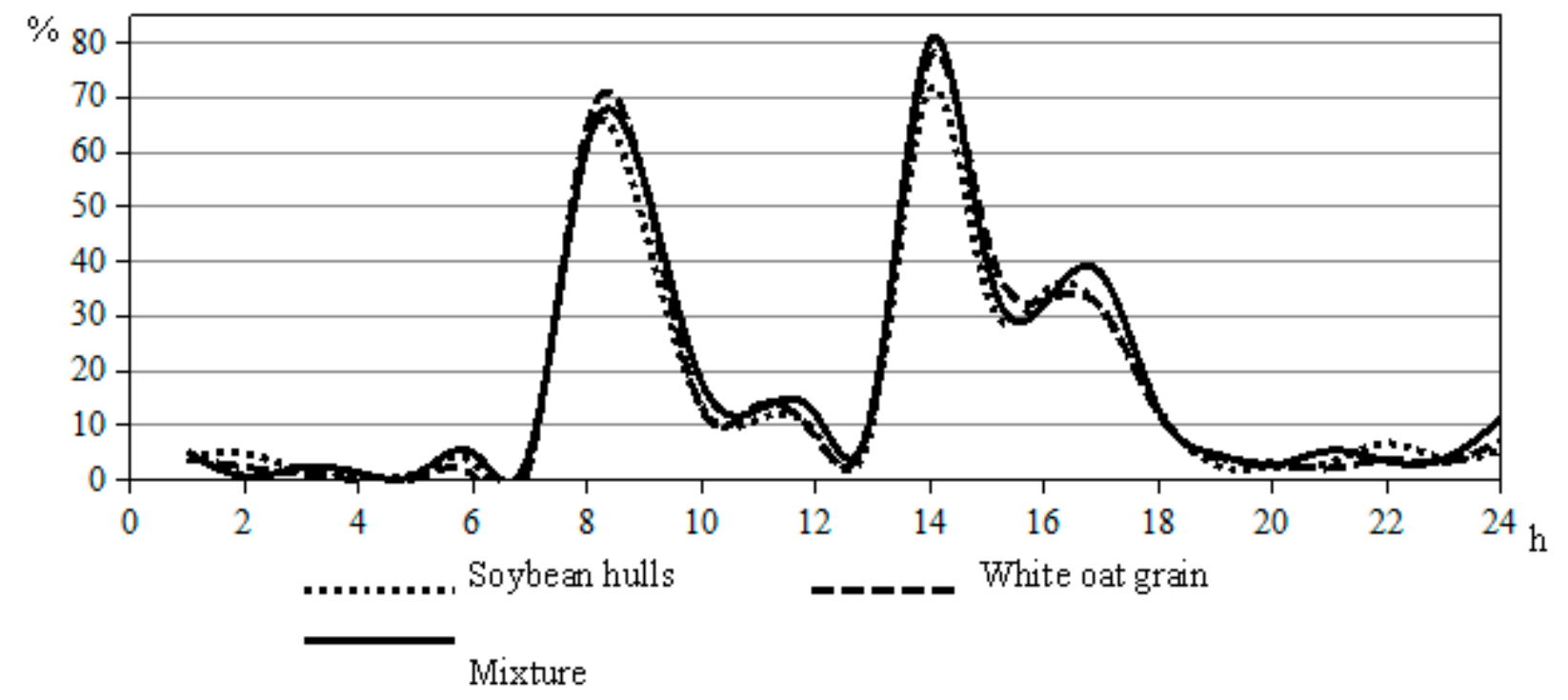

The reduction of rumination time may lead to consequences such as reduction of chewing activity and, consequently, lower saliva secretion, reduction of ruminal $\mathrm{pH}$, and reduction of the acetate: propionate ratio (VAN SOEST, 1994) due to the modification of ruminal flora.

The number of chews per food bolus was influenced by diets, and the animals fed mixture diet had a low number of chews per bolus (Table 5). The lowest number of chews per bolus did not influence chewing time per bolus of the mixture when compared to the others diets, and the number of chews per food bolus presented an inverse correlation with the total rumination time $(78.39 \%$; $\mathrm{P}=0.0001)$. Throughout the day, animals fed diet mixture spent less time chewing food when compared to the diets with white oat grains and soybean hulls, which did not differ significantly from each other. Different from that obtained in this study, Callegaro et al. (2018) stated that the higher the energy density of the diet and the lower the NDF content are, animals perform a lower number of chews per bolus and ruminate lower regurgitated bolus per day.

Pereira et al. (2007) studied the ingestive behavior at different levels of diet neutral detergent fiber and found that its increase from 30 to $60 \%$ increased the number of chews per bolus, the number of bolus per day and, consequently, the number of chews per day and the total chewing time. However, it did not influence chewing time per bolus and the number of chews per minute. This result is different from that obtained in the present study, in which animals fed mixture diet had $56.39 \%$ of the neutral detergent fiber in the dry matter, an intermediate value to the other two diets, i.e., soybean hulls $(66.12 \%)$ and white oat grains $(47.15 \%)$. In vitro organic matter digestibility explains such behavior, where soybean hulls have an initial digestibility (3-24 hours) lower than that of white oat grains, which has a lower final digestibility (24-72 hours).

Digestibility values are reached at different times. In this sense, soybean hulls had a digestibility of $53.45 \%$ at the time of 24 hours, while white oat grains had a $57.40 \%$ digestibility at the time of 12 hours after incubation. Mixture diet, on the other hand, had a better digestibility balance.

Regarding the number of daily chews, animals fed mixture diet presented a lower value in comparison to the diets with soybean hulls and white oat grains. It occurred due to the lower number of chews per bolus food for mixture diet. The lower number of 
chews decreased the maintenance energy used by the animal to process the food in the digestion. Different from this study, Silva et al. (2014) did not obtain differences in rumination activities when studying different carbohydrate sources (ground corn, soybean hulls, and wheat bran) in the diet for confined steers.

Animals fed mixture diet presented better rumination efficiency (Table 6) for both dry matter and neutral detergent fiber. For dry matter efficiency, steers fed diets with individual ingredients showed no difference between them, but regarding neutral detergent fiber efficiency, the diet with white oat grains presented a lower efficiency when compared to soybean hulls, followed by the mixture. This behavior of dry matter rumination efficiency is due to the lower rumination time of the mixture diet since
DM consumption was similar between animals from different diets. The behavior of neutral detergent fiber rumination efficiency is due to the lower rumination time of steers fed mixture diet and to the intermediate intake of the neutral detergent fiber fraction of this diet since this variable is obtained between neutral detergent fiber intake and rumination time.

The difficulty in reducing particle size originating from fibrous materials and the high fiber content can reduce rumination or chewing efficiency of the diet by animals (VAN SOEST, 1994). Also, Silva et al. (2005) stated that food rumination efficacy is positively affected by an increase in diet dry matter. In the present study, white oat grains were supplied without any processing to decrease feed particle, as well as soybean hulls, which had a mean particle of $3.5 \mathrm{~mm}$.

Table 6. Efficiency of rumination of the nutrients of steers fed with different types of concentrates in feedlot.

\begin{tabular}{lccccc}
\hline \multirow{2}{*}{ Rumination efficiency } & \multicolumn{3}{c}{ Diet } & Standard & Probability \\
\cline { 2 - 4 } & Sh & SH/WO & WO & & \\
\hline Dry matter intake, \% BW & 2.58 & 2.69 & 2.62 & 0.10 & 0.2135 \\
Neutral detergent fiber intake, \% BW & $1.60^{\mathrm{a}}$ & $1.42^{\mathrm{b}}$ & $1.16^{\mathrm{c}}$ & 0.05 & $<0.0001$ \\
Dry matter, g DM h$^{-1}$ & $0.0159^{\mathrm{b}}$ & $0.0179^{\mathrm{a}}$ & $0.0157^{\mathrm{b}}$ & 0.002 & $<0.0001$ \\
Neutral detergent fiber, g NDF h$^{-1}$ & $0.0099^{\mathrm{b}}$ & $0.0109^{\mathrm{a}}$ & $0.0072^{\mathrm{c}}$ & 0.001 & $<0.0001$ \\
\hline
\end{tabular}

$\mathrm{BW}=$ body weight; $\mathrm{DM}=$ dry matter; $\mathrm{SH}=$ soybean hulls; $\mathrm{WO}=$ white oat grain.

a,b,c - means with significant differences by Student's t-test $(\mathrm{P}<0,05)$ have different letters in the same row.

According to Missio et al. (2010), who assessed different concentrate proportions in the diet, the result for dry matter rumination efficiency is associated with the higher specific weight of the concentrated fraction and neutral detergent fiber contents of the diet, which decreased as the concentrate fraction in the diet increased. The difference in neutral detergent fiber rumination efficiency between soybean hulls and white oat grains may be related to the lower neutral detergent fiber content present in the white oat grains (Table 2).

Thus, animals fed equal parts of soybean hulls and white oat grains in the concentrate fraction of the diet presented a lower rumination time, chewing time, and number of chews per bolus and day, thus obtaining a rumination efficiency of dry matter and neutral detergent fiber, which resulted in higher feeding time and number of daily meals.

\section{Acknowledgement}

The CAPES, by the post-graduate scholarship received by the first author during the accomplishment of this study. To INTA / Entre Rios for the availability of use of its structure for laboratory analysis. 


\section{References}

ARGENTA, F. M.; BRONDANI, I. L.; ALVES FILHO, D. C.; NORNBERG, J. L.; SEGABINAZZI, L. R.; RESTLE, J.; WEISE, M. S.; BORCHATE, D.; RODRIGUES, L. da S.; MOURA, A. F. de. Comportamento ingestivo de novilhos alimentados com silage de capim papuã (Urochloa plantaginea) x silagem de sorgo (Sorghum bicolor (L.) Moench). Revista Acadêmica: Ciências Agrárias e Ambientais, Curitiba, v. 11, n. 3, p. 243-253, 2013. DOI: 10.7213/academica.011.003.AO04

ASSOCIATION OF OFFICIAL AGRICULTURAL CHEMISTS - AOAC. Official methods of analysis. $16^{\text {th }}$ ed. Arlington: Patricial Cunnif, 1995. 1025 p.

BÜRGER, P. J.; PEREIRA, J. C.; QUEIROZ, A. C.; SILVA, J. F. C. da; VALADARES FILHO, S. de C.; CECON, P. R.; CASALI, A. D. P. Comportamento ingestivo em bezerros holandeses alimentados com dietas contendo diferentes níveis de concentrado. Revista Brasileira de Zootecnia, Viçosa, MG, v. 29, n. 1, p. 236242, 2000. DOI: $10.1590 /$ S1516-35982000000100032

CALLEGARO, A. M.; ALVES FILHO, D. C.; PIZZUTI, L. Â. D.; SEGABINAZZI, L. R.; BRONDANI, I. L.; MARTINI,A.P. M. Comportamento ingestivo de novilhos mestiços terminados em confinamento alimentados com borra de soja. Ciência Animal Brasileira, Goiânia, v. 19, n. 1, p. 1-12, 2018. DOI: 10.1590/1809-6891v19e-28150

CARVALHO, G. G. P.; PIRES, A. J. V.; SILVA, R. R.; RIBEIRO, L. S. O.; CHAGAS, D. M. T. Comportamento ingestivo de ovinos Santa Inês alimentados com dietas contendo farelo de cacau. Revista Brasileira de Zootecnia, Viçosa, MG, v. 37, n. 4, p. 660-665, 2008. DOI: $10.1590 / \mathrm{S} 1516-35982008000400011$

CATTELAM, J.; BRONDANI, I. L.; ALVES FILHO, D. C.; SILVA, J. H. S. da; SEGABINAZZI, L. R.; PIZZUTI, L. Â. D.; MAYER, A. R.; WYZYKOWSKI, A.; PEREIRA, L. B.; MACHADO, D. S. Padrões comportamentais de novilhos confinados com diferentes espaços individuais. Current Agricultural Science and Technology, Pelotas, v. 19, n. 1, p. 82-95, 2013. DOI: 10.18539/CAST.V19I1.3247

FATURI, C.; EZEQUIEL, J. M. B.; FONTES, N. A.; STIAQUE, M. G.; SILVA, O. G. da C. Fibra solúvel e amido como fontes de carboidratos para terminação de novilhos em confinamento. Revista Brasileira de Zootecnia, Viçosa, MG, v. 35, n. 5, p. 2110-2117, 2006. DOI: $10.1590 / \mathrm{S} 1516-35982006000700031$

FREITAS, L. S.; SILVA, J. H. S.; SEGABINAZZI, L. R.; SILVA, V. S. da; ALVES FILHO, D. C.; BRONDANI, I. L. Substituição da silagem de milho por silagem de girassol na dieta de novilhos em confinamento: comportamento ingestivo. Revista Brasileira de Zootecnia, Viçosa, MG, v. 39 , n. 1 , p. $225-232,2010$. DOI: $10.1590 / \mathrm{S} 1516-$ 35982010000100030

LICITRA, G.; HERNANDEZ, T. M.; VAN SOEST, P. J. Standardization of procedures for nitrogen fractionation of ruminant feeds. Animal Feed Science and Technology, Amsterdam, v. 57, n. 4, p. 347-358, 1996. DOI: 10.1016/0377-8401(95)00837-3

LIMA, R. M. B.; FERREIRA, M. A.; BRASIL, L. H. A.; ARAÚJO, P. R. B.; VERÁS, A. S. C.; SANTOS, D. C. dos; CRUZ, M. A. O. M.; MELO, A. A. S. de; OLIVEIRA, T. N. de; SOUZA, I. S. Substituição de milho por palma forrageira: comportamento ingestivo de vacas mestiças em lactação. Acta Scientiarum. Animal Sciences, Maringá, v. 25, n. 2, p. 347-353, 2003. DOI: 10.4025/actascianimsci.v25i2.2029

MARQUES, J. A.; MAGGIONI, D.; ABRAHÃO, J. J. S.; GUILHERME, E.; BEZERRA, G. A.; LUGÃO, S. M. B. Comportamento de touros jovens em confinamento alojados isoladamente ou em grupo. Archivos Latinoamericano Produção Animal, Caracas, v. 13, n. 3, p. 97-102, 2005.

MENDES, C. Q.; TURINO, V. F.; SUSIN, I. Comportamento ingestivo de cordeiros e digestibilidade dos nutrientes de dietas contendo alta proporção de concentrado e diferentes fontes de fibra em detergente neutro. Revista Brasileira de Zootecnia, Viçosa, MG, v. 39, n. 3, p. 594-600, 2010. DOI: 10.1590/S151635982010000300019

MENDONÇA, S. S.; CAMPOS, J. M. S.; VALADARES FILHO, S. C.; VALADARES, R. F. D.; SOARES, C. A.; LANA, R. P.; QUEIROZ, A. C.; ASSIS, A. J.; PEREIRA, M. L. A. Comportamento ingestivo de vacas leiteiras alimentadas com dietas à base de cana-de-açúcar ou silagem de milho. Revista Brasileira de Zootecnia, Viçosa, MG, v. 33, n. 3, p. 723-728, 2004. DOI: 10.1590/ S1516-35982004000300021

MISSIO, R. L.; BRONDANI, I. L.; ALVES FILHO, D. C.; SILVEIRA, M. F. da; FREITAS, L. da S.; RESTLE, J. Comportamento ingestivo de tourinhos terminados em confinamento, alimentados com diferentes níveis de concentrado na dieta. Revista Brasileira de Zootecnia, Viçosa, MG, v. 39, n. 7, p. 1571-1578, 2010. DOI: 10.1590/S1516-35982010000700025

MOURA, A. F. de; ALVES FILHO, D. C.; BRONDANI, I. L.; MACHADO, D. S.; RODRIGUES, L. da S.; CARDOSO, G. dos S.; ADAMS, S. M.; SILVA, M. B. da; DOMINGUES, C. C.; BORCHATE, D. Ingestive behavior of feedlot-finished steers submitted to energy supply patterns. Semina: Ciências Agrárias, Londrina, v. 39, n. 6, p. 2703-2716, 2018. DOI: 10.5433/1679-0359.2018v39n6p2703 
NATIONAL REQUIREMENT COUNCIL - NRC. Nutrient requirements of beef cattle. $7^{\text {th }}$ ed. Washington: National Academy Press, 2001. 242 p.

PAZDIORA, R. D.; BRONDANI, I. L.; SILVEIRA, M. F. da; ARBOITTE, M. Z.; CATTELAM, J.; PAULA, P. C. de. Efeitos da frequência de fornecimento do volumoso e concentrado no comportamento ingestivo de vacas e novilhas em confinamento. Revista Brasileira de Zootecnia, Viçosa, MG, v. 40, n. 10, p. 2244-2251, 2011. DOI: 10.1590/S1516-35982011001000026

PEREIRA, J. C.; CUNHA, D. de N. F. V. da; CECON, P. R.; FARIA, E. de S. Comportamento ingestivo e taxa de passagem de partículas em novilhas leiteiras de diferentes grupos genéticos submetidas a dietas com diferentes níveis de fibra. Revista Brasileira de Zootecnia, Viçosa, MG, v. 36, n. 6, p. 2134-2142, 2007. Suplemento. DOI: 10.1590/S1516-35982007000900025

PINTO, A. P.; MARQUES, J. A.; ABRAHÃO, J. J. S.; NASCIMENTO, W. G.; COSTA, M. A. T.; LUGÃO, S. M. B. Comportamento e eficiência ingestiva de tourinhos mestiços confinados com três dietas diferentes. Archivos de Zootecnia, Córdoba, v. 59, n. 227, p. 427-434, 2010.

SILVA, R. R.; SIlvA, F. F.; CARVAlHO, G. G. P.; FRANCO, I. L.; VELOSO, C. M.; CHAVES, M. A.; BONOMO, P.; PRADO, I. N.; ALMEIDA, V. S. Comportamento ingestivo de novilhas mestiças de holandês x zebu confinadas. Archivos de Zootecnia, Córdoba, v. 54, n. 1, p. 75-85, 2005.

SILVA, V. S. da; ALVES FILHO, D. C.; FREITAS, L. da S.; BRONDANI, I. L.; AZEVEDO JUNIOR, R. L. de; TEIXEIRA, O. de S.; BORCHATE, D. Sources of carbohydrates in the ingestive behavior of feedlot steers. Revista Brasileira de Zootecnia, Viçosa, MG, v. 43, n. 5, p. 273-277, 2014. DOI: 10.1590/S151635982014000500008
STATISTICAL ANALYSIS SYSTEM - SAS Institute Inc. SAS Language Reference. Version 9.2. Cary: SAS Institute, 2009.

THOMPSON, R. K.; MUSTAFA, A. F.; MCKINNON, J. J.; MAENZ, D.; ROSSNAGEL, B. Genotypic differences in chemical composition and ruminal degradability of oat hulls. Canadian Journal of Animal Science, Ottawa, v. 80, n. 2, p. 377-379, 2000. DOI: 10.4141/A99-132

TILLEY, J. M. A.; TERRY, R. A. A two-stage technique for the in vitro digestion of forage crops. Journal of the British Grassland Society, Reaseheath, v. 18, n. 2, p. $104-$ 111, 1963. DOI: 10.1111/j.1365-2494.1963.tb00335.x

VAN SOEST, P. J. Nutritional ecology of the ruminant. $2^{\text {th }}$ ed. Ithaca: Cornell University Press, 1994. 476 p.

VAN SOEST, P. J.; ROBERTSON, J. B.; LEWIS, B. A. Methods for dietary fiber, neutral detergent fiber, and nonstarch polysaccharides in relation to animal nutrition. Journal of Dairy Science, Champaign, v. 74, n. 10 , p. $3583-3597,1991$. DOI: $10.3168 /$ jds.S00220302(91)78551-2

WEISS, W. P.; CONRAD, H. R.; ST. PIERRE, N. R. A theoretically-based model for predicting total digestible nutrient values of forages and concentrates. Animal Feed Science and Technology, Amsterdam, v. 39, n. 1-2, p. $95-$ 110, 1992. DOI: 10.1016/0377-8401(92)90034-4

ZAMBOM, M. A.; SANTOS, G. T. dos; MODESTO, E. C.; ALCALDE, C. R.; GONÇALVES, G. D.; SILVA, D. C. da; SILVA, K. T. da; FAUSTINO, J. O. Valor nutricional da casca do grão de soja, farelo de soja, milho moído e farelo de trigo para bovinos. Acta Scientiarum, Maringá, v. 23, n. 4, p. 937-943, 2001. DOI: 10.4025/ actascianimsci.v23i0.2648 